\title{
A Study on the Role of Government Audit in Promoting the Growth of Central Enterprises
}

\author{
Qiu Xia ${ }^{1}, \mathrm{Ke} \mathrm{Gao}^{2}$, Kai Wang ${ }^{3}$ \\ ${ }^{1}$ The School of Government, Central University of Finance and Economics, Beijing, P. R. China \\ ${ }^{2}$ Development Research Center of Shandong Provincial People's Government, Jinan, P. R. China \\ ${ }^{3}$ Department of Computer Science, Peking University, Beijing, P. R. China
}

Email address:

longyanshun2005@163.com (Qiu Xia),gkfly@126.com (Ke Gao),wangkaicueb@163.com (Kai Wang)

\section{To cite this article:}

Qiu Xia, Ke Gao, Kai Wang. A Study on the Role of Government Audit in Promoting the Growth of Central Enterprises. Journal of Finance and Accounting. Vol. 6, No. 5, 2018, pp. 127-133. doi: 10.11648/j.jfa.20180605.14

Received: November 17, 2018; Accepted: December 5, 2018; Published: December 6, 2018

\begin{abstract}
As the pillar of state-owned economy, the central enterprises undertake social responsibilities and political tasks different from other enterprises. In recent years, government audit organs have found through auditing that many problems existed in financial management and accounting, operating management, and the implementation of the spirit of the Eight Rules of Central Committee of the CPC and regulations on honest work in central enterprises. Therefore, consummating audit of central enterprises and strengthening supervision over state-owned enterprises and assets are of great importance to promoting central enterprises to deepen reforms, improve operating management, regulate the exercise of power, and enhance the quality and performance of development. Yet defining the role of government audit in the growth of central enterprises is a major prerequisite to complete audit of central enterprises. Through the study of historical changes of Chinese audit environment and present problems analyzing the government audit's role, character evolution, the results can be drawn that the roles of government audit in promoting the development of the central enterprises are as follows: the supervisor of legal compliance, the discoverer of the problems and risks, and the role of promoting the central enterprises to perfect internal control, implement major national policy decisions. On that basis, some suggestions on how to play the above-mentioned roles are given.
\end{abstract}

Keywords: Central Enterprises, Government Audit, Role, Role Evolution

\section{Research Background and Significance}

The Fourth Plenary Session of the 18th CPC Central Committee and Opinions on Strengthening Audit Work (here in after referred to as the Opinions) issued by the State Council in 2014 put forward new requirements to auditing, which means that audit shall not only cover state-owned assets and resources as well as the fulfillment of economic responsibilities of leading cadres, but shall also further achieve functions of government audit-revealing problems existed in the execution of national policies and measures and promoting the campaign of combating corruption and upholding integrity; taking great pains to reveal prominent conflicts and hidden dangers in the operating of socialist market economy, and proposing suggestions on systems and mechanisms as references in government decision-making. On this basis, the session and the Opinions further clarified the important role of government audit.

Central enterprises are widely different from other types of enterprises in economic and social functions due to their special enterprise character. This article focuses on several problems as below: What is the role definition of government audit in the development of central enterprises? How do these roles evolve? How to play the above-mentioned roles of government audit? These researches are helpful for the government to do a good job in auditing central enterprises and better promoting the development of central enterprises. 


\section{Literature Review}

With high-quality resources, central enterprises are backbone of state-owned enterprises. However, since central enterprises have many subordinate companies with intricately interwoven interests without efficient control and supervisory mechanism, which leads to a result that many problems constantly arise such as central enterprises failing to get approval for major investment projects and engineering construction and use of large funds, group decision-making procedure performed loosely, and losses and wastes caused by unregulated large-amount guarantee and money lending. Therefore, as an important external supervisor for central enterprises, government audit plays a vital role in accelerating the deepened reform of central enterprises, implementing major national decisions, improving the performance of operating management and so forth. While the key to advancing government audit work is to clarify what roles shall government audit play, and once the roles are identified, corresponding responsibilities will become clear and it will be easier to choose policy instruments to rectify the problems pinpointed by government audit. This article studies the above-mentioned problems.

For now, there is no paper among current literature that systematically discussed the role of government audit in the development of central enterprises, while related studies concentrated on the analysis of government audit itself and only few literature discussed role definition of government audit at the macro level and importance. For example, Yang Tao, Xie Zhihua, Liu Liyun expounded on the connotations of government audit at the macro level and how to define the role of government audit $[1,2,3]$. As for the relationship between public governance and macro-control and government audit, Zhang Weiwei discussed the role definition of government audit and development strategy under national governance system, and analyzed the role which government audit should play in the reform of state-owned enterprises [4]. While Yao Airan analyzed how to explore potential of government audit in intensifying national macro-control [5]. All in all, among existing literature, only a few articles studied the role of government audit, and related studies are not specific and comprehensive enough. Moreover, no literature is found to have systematically discussed the role definition of government audit and role evolution in the development of central enterprises for now.

\section{Role Definition of Government Audit and the Framework of Role Evolution}

\subsection{Influencing Factors on the Role of Government Audit}

Peng Peng argued that the roles that the government play are determined by different economic, political and social patterns [6]. With the role of government audit falling into the category of government role and based on the analyses of different authors, four factors can be concluded that influencing government audit's role: socio-economic situation, new awareness of the role of audit, politics-democracy relationship and deployment of national strategy. The above four factors constitute the macro environment for audit.

\subsubsection{Politics-democracy Relationship}

In China, the concept that people are masters of the country is the core of socialist democracy, as people endow national sectors with the power to operate and enable the country to manage public resources and act accordingly, namely public fiduciary duty determines governmental powers. Therefore, government audit is also empowered by the public and serves as an important means for the public to supervise public sectors [7, 8, 9]. Hence, if politics-democracy relationship changes at different periods or the public put forward a new requirement for the government, the status and function of government audit should be changed, in another word, the roles played by government audit should be changed.

\subsubsection{Socio-economic Situation}

Karl Marx and Friedrich Engels believe that economic basis determines the superstructure, while government audit system which falls into the category of superstructure, is determined by the economic basis of national economic situation. Meanwhile, the stage of social development and problems arising determine the roles that government audit should play to a great extent. The higher the level of national economic development is, the more roles that government audit will play and the more important these roles will be. Because the higher the social productive force is, the more developed the economy will be and the broader the national public expenditure will be, also the more economic and social problems there will be.

\subsubsection{New Awareness of the Role of Audit}

Knowledge starts with practice. When government audit practice and academia deepen their studies of audit, people are gaining an increasingly deep cognition of government audit. When practice and study give rise to new auditing theories, the role of government audit in socialist construction will have new connotations and denotations. Then, theory reacts upon practice and further guides audit work.

\subsubsection{Deployment of National Strategy}

Major national decisions will exert a direct influence on the status, nature of work and due functions of government audit, namely national strategy deployment will directly change the role definition of government audit, to make it serve nation-building and complete tasks and missions at different times better.

\subsection{Role Definition of Government Audit and the Framework of Evolution}

The role played by government audit is not changeless. Firstly, the four factors exert a direct influence on role 
definition of government audit; Secondly, when the audit environment made up of these four changes, the role of government audit will change accordingly. That is to say, the role of government audit will evolve at different times. The evolution framework is shown as Figure 1:

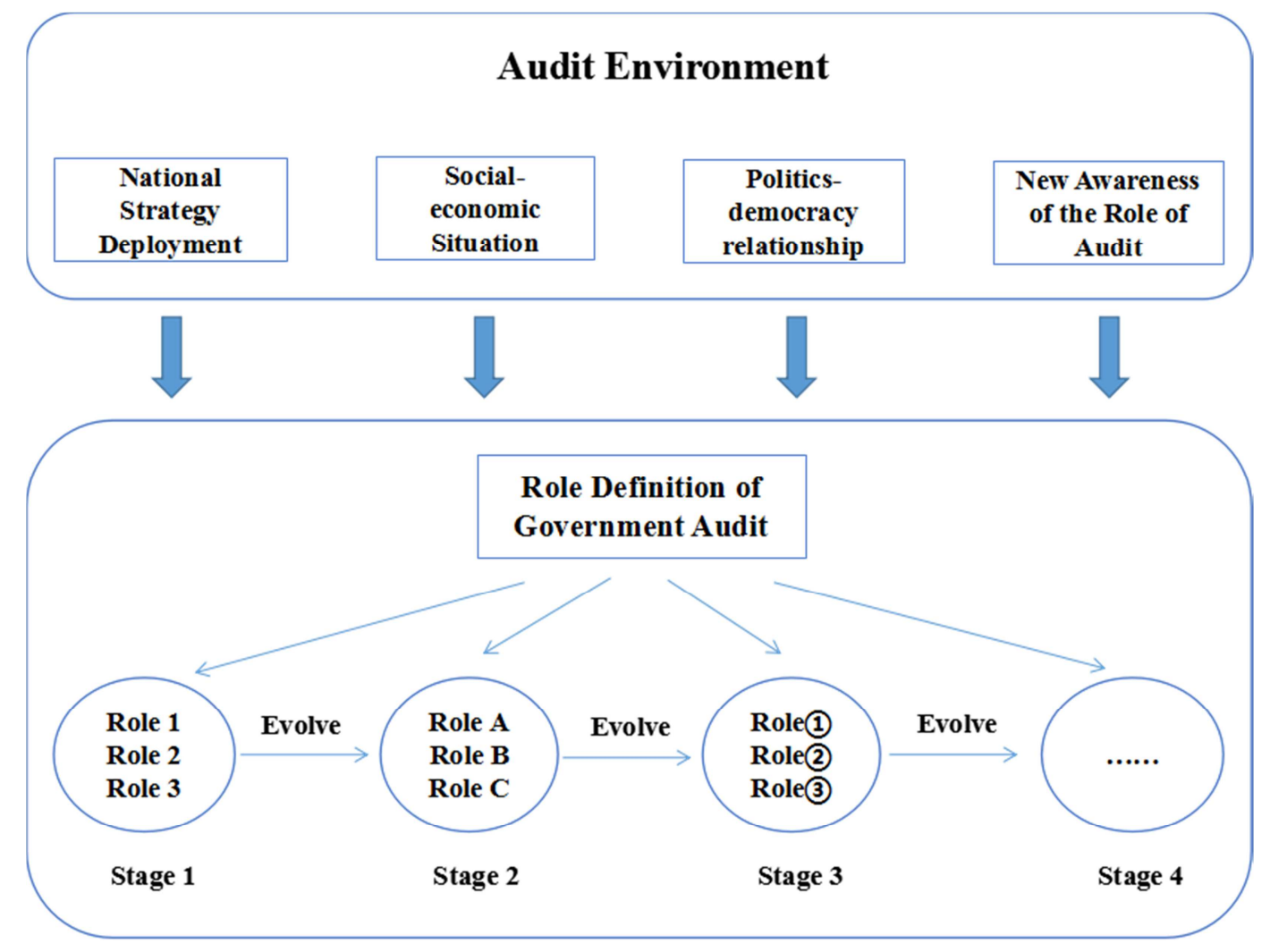

Figure 1. Role of government audit and role evolution framework.

\section{Role Definition and Evolution of Government Audit in the Growth of Central Enterprises}

\subsection{Role Definition and Evolution}

Based on the government audit's role and role evolution framework analyzed above, the government audit's role at different stages can be studied by referring to the division of stages of evolution of audit functions proposed by Zhou Jiqiu, Chen Taihui as well its role definition and evolution in the growth of central enterprises [10,11].

\subsubsection{The Stage of Fiscal Supervision (1983-1987)}

In September 1983, China established the National Audit Office in accordance with the Constitution, with the purpose of boosting economic performance and safeguarding financial and economic disciplines. Furthermore, effective control over major affairs and relaxed control over minor aspects were exercised. Meanwhile, audit of economic responsibility of state-owned enterprises was conducted at a certain level. According to the aforementioned model, at this stage, it was national decision factor that chiefly and directly determined the role of government audit. And the corresponding role of government audit was supervisor of financial and economic disciplines.
At this stage, the nature of most state-owned enterprises was ownership by the whole people. The National Audit Office supervised basic works of business management and economic responsibility of factory directors, and punished those who violated financial and economic disciplines to avoid major loss of assets.

\subsubsection{The Stage of Macro-control Stage (1988-1994)}

In the late $1980 \mathrm{~s}$, the development of Chinese economy experienced great changes-prices rose substantially and inflation emerged obviously. In the 5th plenary session of the 13th CPC Central Committee in 1989, the country adjusted economic strategy and policy which required improvement and rectification of national economy in a period of three years or longer to keep the growth rate of prices less than $10 \%$.

In order to cope with inflation and obvious rising of price in national macroeconomic environment, the government proposed a policy which included rectifying economic order and comprehensively deepening reform in economy, increasing effective supply to resolve the conflict between demand and supply, and declining inflation rate step by step and decreasing prices of retails. As the main portion in state-owned economy, central enterprises can exercise a function of macroeconomic control. Therefore, according to the model shown in Figure 1, socio-economic situation at this stage underwent great changes and influenced the role of 
government audit, adding a role as a regulator to the previous role as a supervisor. While government audit also played the same roles of supervisor and regulator in the development of central enterprises.

\subsubsection{The Stage of Internal Control (1995-2007)}

National People's Congress passed the Audit Law in 1994, establishing an auditing system featuring the combination of "upper-level audit" and "equal-level audit" and "two reports" which further clarified the domain, scope and responsibility of auditing supervision.

At this stage, socio-economic situation changed, while people became increasingly demanding for fiduciary in a public fiduciary duty and required open and transparent government information. The aforementioned factors changed the role of government audit. The Report on the Work of the Government in this period issued by the central government made clear that government audit should play a major part in auditing economic responsibility of leaders of state-owned enterprises and financial institutions and preventing corruption. Meanwhile, all agencies and departments were required to strengthen internal management and rectify problems revealed. It followed that the roles of government audit became supervisor and impeller for all organizations and sectors to reinforce internal management for leaders of central enterprises as well as the heads of financial institutions.

In this period, the National Audit Office further reinforced the supervision over central enterprises and advanced the improvement of their internal control in the context of the reform of state-owned enterprises.

\subsubsection{The Stage of Involvement in National Governance (2008 to Present)}

Liu Jiayi from the National Audit Office believes that the present times is the critical stage of the changes in governmental functions, during which government audit should be defined as a key part of national governance guaranteeing long-term social stability and order as well as healthy economic growth. Chinese economic and social development gradually entered a new era that national strategic goal was changed into building a more effective and transparent government. Auditors and auditees support and collaborate with one another, rather than antagonistic. It is necessary to comprehensively supervise the exercise of power, the use of capital and the allocation of resources, and to improve national governance. At this stage, as government audit practice advances, administrators have new awareness of the roles that audit shall play. A change of this factor leads to a change in the role of government audit.

The Report on the Work of the Government in 2012 stressed the necessity to strengthen the audit of key fields, departments and funds. According to the analytical framework of Figure 1, people developed a new awareness of the role of audit at this stage, as the role became supervisor, problem-finder and nation-building impeller. Against this backdrop, the roles played by government audit in the development of central enterprises are supervisor, problem-finder and impeller as well.

\subsection{Analysis of Role Definition of Government Audit in the Development of Central Enterprises at the Current Stage}

To further study role definition of government audit in the growth of central enterprises at the current stage and provide audit institutions with more detailed references for future work, this article focuses on discussing the positioning of government audit in the development of central enterprises at the fourth stage. This is divided into five parts: monitoring whether central enterprises are run in accordance with laws and regulations; finding major risks and loopholes of central enterprises; driving central enterprises to build and improve a high-quality internal control system; pushing central enterprises to implement major decisions of the party and the country; prompting local governments to create a sound business environment and reduce the burden of central enterprises. The brief is shown as Table 1:

Table 1. Roles of government audit.

\begin{tabular}{|c|c|c|}
\hline Role of Government audit & Responsibility & Audit Content \\
\hline $\begin{array}{l}\text { Supervisor } \\
\text { Finder }\end{array}$ & $\begin{array}{l}\text { Monitoring whether central enterprises are run in accordance with laws and regulations. } \\
\text { Revealing and finding major risks and hidden perils in central enterprises. } \\
\text { Driving central enterprises to build and improve a high-quality internal control system. }\end{array}$ & State of operation \\
\hline \multirow[t]{2}{*}{ Impeller } & Pushing central enterprises to implement major state decisions. & $\begin{array}{l}\text { Implementing major party } \\
\text { and national decisions }\end{array}$ \\
\hline & $\begin{array}{l}\text { Prompting local governments to create a sound business environment and ease the burden } \\
\text { of central enterprises. }\end{array}$ & Business environment \\
\hline
\end{tabular}

\subsubsection{Government Audit Is Supervisor Monitoring the Compliance Management of Central Enterprises}

Legitimate operation is the bottom line that every enterprise shall hold on to. For central enterprises who enjoy a special status to some degree, government audit needs to adhere to problem-orientated principle and find and reveal major problems existing in daily operating management activities of central enterprises, especially severe malfeasance, and problem that would cause capital loss or potential property loss. Those leaders of central enterprises who severely violate laws and disciplines, including benefiting themselves at the expense of public interests, extravagance and wastes, will be investigated and punished, thus regulating the growth of central enterprises and allowing government audit to truly act as a supervisor monitoring whether central enterprises operate in compliance with laws and regulations. 


\subsubsection{Government Audit Is an Impeller of Driving Central Enterprises to Build and Improve a High-quality Internal Control System}

As the reform of state-owned enterprises is deepened and modern enterprise system was established, central enterprises came to design an internal control management system, but they also should avoid the incongruity between internal control system and the reality, and prevent the expansion of real economy from triggering runaway power, decision-making deviation and management failure. Due to the particularity of central enterprises, government audit is needed to drive central enterprises to reinforce their internal management and control and nip hidden perils in the bud. Moreover, it is advisable to guide central enterprises to perfect their self-restricting mechanism and push central enterprises to improve efficiency, to make sure that their management is capable of truly fulfilling their duties and responsibilities.

\subsubsection{Government Audit Is the Finder of Major Risks and Loopholes of Central Enterprises}

It is learned from the analysis of audit reports on central enterprises released by the National Audit Office recently, government audit found quite a few significant risks and loopholes existing in central enterprises in recent years. For example, some central enterprises are still confronted with a number of problems that affect their sustainable development, including high asset-liability ratio, difficulty in paying the debt sustainably to the extent that there is heavy debt burden, insufficient input in science and technology, feeble growth of main business, and weak innovation capability. As central enterprises gain an increasingly deep understanding of risks, their ability to prevent and defuse risks is greatly improved. However, as China is now at the critical stage of economic structural adjustment, unpredictable risks and problems are unavoidable. Moreover, as reforms are deepened, types of risk and uncertainty of occurrence will increase significantly.

Government audit focuses on helping central enterprises prevent and neutralize major risks, paying more attention to operating management and risk control of central enterprises, and urging central enterprises to properly deal with risks facing the enterprises.

\subsubsection{Government Audit Is an Impeller of Driving Central Enterprises to Implement Major National Decisions}

Central enterprises should energetically implement major national decisions and proactively carry out the work. Besides daily operation and development, central enterprises also need to take the initiative to fulfill their social responsibility. Meanwhile, central enterprises undertake some tasks of national macro-control and function as a controller of the direction of national economic and social development. At this stage, central enterprises should proactively promote national strategic construction and drive various pilot reform programs, while these responsibilities and functions are what private enterprises do not have. Government audit should play a potent role as an impeller in the process of central enterprises implementing major party and national decisions and making full use of state-owned capital.

In the case of central enterprises loosely implementing major national decisions with slow progress or making insufficient use of state-owned capital, government audit should advise and push them to carry out major party and national decisions.

\subsubsection{Government Audit Is an Impeller Who Drives Local Governments to Create a Sound Business Environment and Ease the Burden of Central Enterprises.}

In May 2016, Premier Li Keqiang first proposed the necessity for the government to "streamline administration, delegate power and strengthen regulation, and optimize service" as well as increase efficacy. In the audits and investigations of economic responsibility of central enterprises in these two years, the National Audit Office performed several specialized audits of enterprise-related charges and concentrated on keeping an eye on the reform of administrative approval system of governments. It turns out that many places have problems that central enterprise needs to construct on a loan and occupy lots of funds when taking over a local project, and the problems above all are to the disadvantage of truly easing the burden of central enterprises and energizing them.

Government audit helps prompt local governments to optimize their service attribute and increase their efficiency as required by the Central Government and the State Council. Meanwhile, government audit puts forward important policy suggestions by keeping a watchful eye on the business environment of central enterprises, to remove institutional hindrances to the growth of central enterprises. In a manner of speaking, government audit is an impeller who pushes local governments to create a sound business environment and ease the burden of central enterprises.

\subsection{Summary}

From the role definition of government audit in the growth of central enterprises and the changes in the roles over these years, some disciplines can be found. Their similarity is that the core role of government audit in the development of central enterprises has never changed, namely the role as an economic regulator has always been the core role of government audit in central enterprises. The differences lie in that the scope, content and intensity of supervision conducted by government audit are changed; next, government audit will have more roles because of the changes in the audit environment at different periods.

\section{Suggestions on the Realization of the Role of Government Audit}

Based on the above analysis, the following suggestions can be proposed on the realization of the role of government audit in the development of central enterprises: 


\subsection{Making Clear the Goal and Mission of Government Audit}

Government audit institutions should set a goal and mission in line with the people's will according to the Constitution. At the current stage, the mission of government audit should be promoting the legitimate development of central enterprises, ensuring public resources are utilized efficiently and rationally; on this basis, implementing major national decisions, advancing the implementation of macro-control policy, and providing a strong support to sustainable economic development, constant improvement of people's livelihood and social fairness and justice.

\subsection{Confirming the Authority of Government Audit Legally}

The basis and key for government audit to performing their functions and playing their roles is: legally constantly improving government audit-related legal system and making clear the status of government audit in laws and regulations. Only in this way can government audit be better performed, create public value more effectively and drive central enterprises to carefully implement national macroeconomic policy more efficiently, complete development targets and control tasks assigned by the party and the country at different stages of development, improve their business performance, and attain high-quality growth.

\subsection{Perfecting Operations Management Corresponding to the Role of Government Audit}

To play the roles effectively, government audit needs to integrate various resources of the country, work out plans and take a series of measures to achieve the goal and even accomplish the mission. Besides the support of other external resources, audit institutions also need to persist in strengthening audit with science and technology and advance the professionalism of auditing.

Furthermore, online education and training platform for auditor cadres, training in collaboration with colleges, systematic training, audit practice training and other means are used to train a batch of professionals who are on top of big data audit -related know-how, including computer science, mathematical statistics and database, and are familiar with acquisition and analysis of big data, data extraction and visual representation, to provide big data application and innovation of audit thinking with a reserve and support of professionals.

\section{Conclusions}

Socio-economic situation, new awareness of the role of audit, politics-democracy relationship and deployment of national strategy are the four factors that constitute the government audit environment, which determines the role of government audit. When the audit environment changes, the role of government audit will also change. In different audit environments, the roles of government audit may increase, but the role of supervisor has always been the core role of government audit.

Since the establishment of the National Audit Office in 1983, government audit has successively acted as the supervisor of legal compliance of central enterprises; Macroeconomic regulators; Discoverer of problems and risks; the promoter of the improvement of internal control of central enterprises and the implementation of major state decisions; the promoter of pushing local governments to create a good business environment and reduce the burden of central enterprises. The above-mentioned roles play an important role in promoting the development of central enterprises.

As for how to facilitate the realization of the government audit's role, this article suggests that government audit institutions should at first pinpoint their own goals, set organizational missions, strengthen the cooperation of policy instruments corresponding to the roles and duties of government audit by continuously perfecting the legal system, and constantly train high-quality audit professionals. In this way, the role of government audit can be better realized. In the future, government audit should also make full use of big data technology, deeply explore and reveal various problems existing in the development of central enterprises, and prevent them before they happen.

One of the deficiencies of this article lies in the lack of data on corresponding cases for analysis, which will be collected and sorted in follow-up study.

\section{References}

[1] Yang Tao (2013). On Role Definition of Government Audit. Money China (Academic Edition), 5, 229.

[2] Xie Zhihua, Tao Yuxia (2013). On Role definition of Government Audit. Audit \& Economy Research, 28 (02), 9-15.

[3] Liu Liyun (2009). Role Definition of Government Audit in China. China Audit, 14, 41-43.

[4] Zhang Weiwei (2014). Government Audit Under National Governance System: Role, Positioning and Development Strategy. Symposium on "Government Audit and National Governance" in Jiangsu province, 8.

[5] Yao Airan (2006). Role Definition of Government Audit in Strengthening and Improving Macro-Control. Auditing Research, 5, 15-18.

[6] Peng Peng (2002). Government role theory. China Social Science Press, 12, 229-256.

[7] Liang Yu (2017). Research on improving the theoretical framework of government audit based on public accountability. National circulation economy, 2, 85-86.

[8] Wang Mingzhu, Zhang Jie (2017). National audit of government governance effectiveness and implementation path. Industry and technology BBS, 22, 196-197.

[9] Chen Weiyu, Wang Dan (2018). Research on the whole-process cooperation mechanism between national audit institutions and citizens -- based on the perspective of good governance of the country. Friends of accounting, 1, 146-149. 
[10] Zhou Jiqiu (2014). A Study of the Evolution of Functions of Government Audit in China. Contemporary Economics, 17, 64-65.
[11] Chen Taihui (2008). A Study of Laws of the Evolution of Functions of Government Audit in China. Huazhong University of Science and Technology. 